\title{
The Guiana Shield Reviewed
}

\author{
by Allan K. Gibbs and Christopher N. Barron
}

\begin{abstract}
The Guiana Shield of northern South America has much to contribute to the study of Earth history. It includes one of the world's largest granite-greenstone terranes and a Precambrian anorogenic, felsic volcanic and plutonic magmatic province of equally important dimension. Moreover, much of the crust of the region appears to have originated during the Early Proterozoic rather than the Archaean, as in better-known Precambrian regions elsewhere. This article outlines the main features of the Guiana Shield and its geological history, reviewing the current literature and pointing to some of the outstanding problems to be resolved.
\end{abstract}

\section{Working on the Guiana Shield}

The geology of the Guiana Shield was established in broad outline between about 1860 and 1910 by pioneers like C.B. Brown, J.G. Sawkins, J.B. Harrison, L. Agassiz and O.A. Derby. Their work was accomplished despite the difficult conditions which still persist: limited access imposed by tropical rainforests, lack of roads, rivers with numerous rapids and falls, and the malaria and yellow fever endemic in parts of the region. Dense forests cover most of the shield, except for savanna areas in eastern Venezuela, southern Guyana, along the Brazil-Suriname border and in the Pakaraima Mountains (see Fig. 3 for locations).

In the past few decades, aerial photography, airborne geophysics, radar and satellite imagery, isotope geochronology and improved transport have made it possible to map much of the shield at scales of 1:250000 or less, and the geological history has been determined with more precision than most geologists from temperate regions might suspect. Summaries of recent work in various parts of the shield are presented by Bosma et al. (in preparation), Choubert (1974), Lima et al. (1974), Martin (1974), Mendoza (1974), Montalvao et al. (1975), Oliveria et al. (1975), Pinheiro et al. (1976) and Berrangé (1977).

The diversity of languages - Portuguese, Spanish, English, Dutch and French - in which the geology of the region is written, and the restriction of most of the works to relatively obscure government publications and regional symposia are responsible for the continuing lack of knowledge about the Guiana Shield by the wider geological community.

The majority of fresh rock exposures are in rivers and streams (Fig. 1), and the most resistant lithologies also occur with little weathering on the hills. Mapping by both ground and remote surveys can make use of properties of the highly developed weathering zone, for the lateritic soils and saprolites retain some of the minerals and textural properties of the rocks from which they were derived. The topography and, in some instances, vegetation may also be closely related to bedrock lithology and structure. Air photographs and satellite images are thus useful, despite the dense forest (see cover photo).

\section{Broad Geological Outline}

The Guiana Shield is the northern portion of the Amazonian Platform, extending from the Atlantic margin to the Amazon basin (Fig. 2). On the west it forms the basement to the Andean foreland basins. The Guaporé or Central Brazilian Shield south of the Amazon basin completes the Amazonian Platform.

The Guiana Shield can be subdivided into a granulite and gneiss terrane in eastern Venezuela with Archaean protoliths

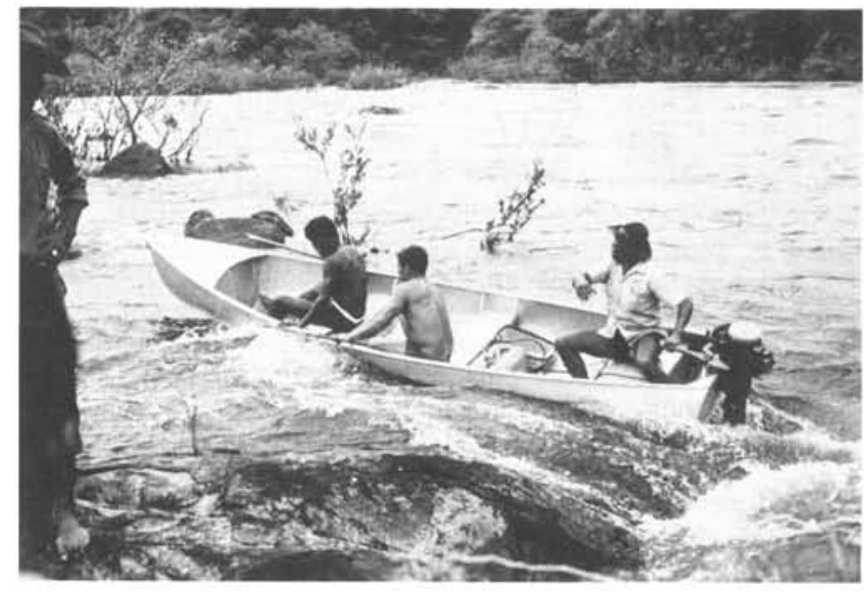

Figure 1: Outcrops at Devil's Hole rapids on the Cuyuni River, Guyana.

(the Imataca Complex), an Early Proterozoic (2.3-1.9 Ga) granite-greenstone-gneiss terrane in a zone $300-400 \mathrm{~km}$ wide along the Atlantic margin, and a central and western portion that has an extensive Middle Proterozoic (1.9-1.6 Ga) platform cover (Fig. 4). In the latter region, anorogenic felsic volcanic and plutonic rocks and associated continental sediments intrude or are deposited on an older metamorphic basement.

Early Proterozoic events of about $2 \mathrm{Ga}$, involving metamorphism, deformation and associated granitoid intrusion, affected the basement over most of the shield, and are referred to collectively as the Trans-Amazonian Orogeny. There are also Proterozoic and younger mafic dikes, sills and flows in addition to several alkaline complexes.

\section{The Imataca Complex: Archaean Granulites and Gneisses}

The Imataca Complex is the only part of the shield that has yielded Archaean ages, though the metamorphic peak appears to have been Trans-Amazonian. The complex is in faulted contact with the surrounding Precambrian rocks. There is also a series of southeast-dipping thrusts (Ascanio, 1975) involving both the younger granite-greenstone-gneiss terranes and the Imataca Complex.

In one part of the Complex, Dougan (1977) showed that the parent rocks of the granulites and amphibolite-facies gneisses were predominantly acidic, calc-alkaline igneous rocks of continental affinity. Intermediate granulites, mafic gneisses, 


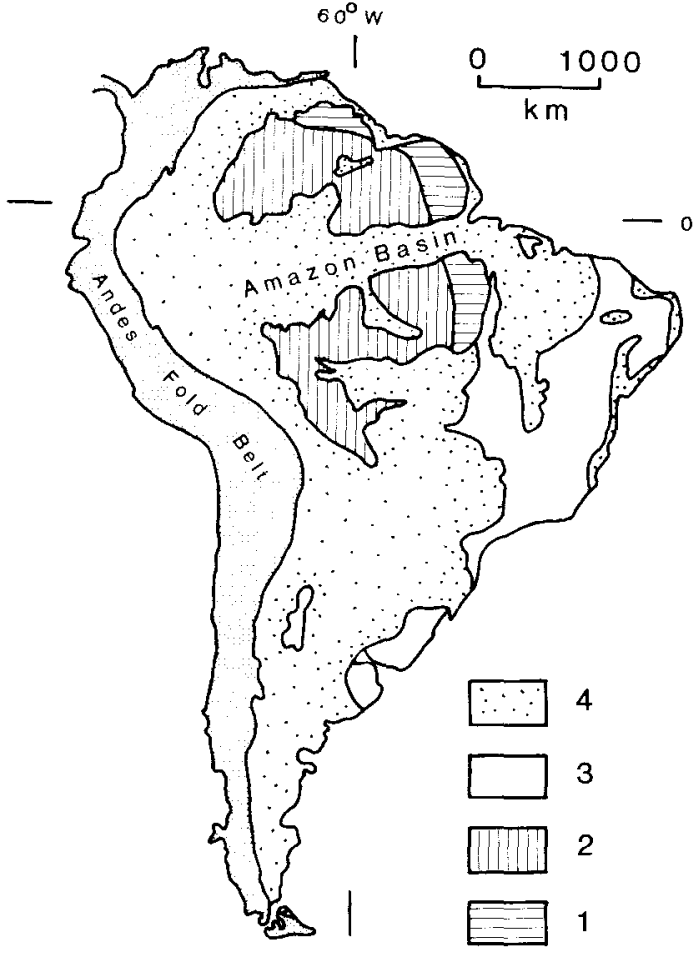

Figure 2: South America, showing the Guiana Shield (north of the Amazon Basin) and the Guapore Shield (south of the Amazon). Together they make up the Amazon Platform. Key: 1 - greenstone, gneiss and granite terranes, 2 - regions with Middle Proterozoic platform cover and granitoid intrusives, 3 - other Precambrian shields, 4 - Phanerozoic sedimentary cover.

metasedimentary gneisses, iron formation, minor ultramafic granulites, dolomitic marbles and anorthosites make up the remainder of the Imataca lithologies.

A detailed geochronological study by Montgomery and Hurley (1978) of Imataca banded gneisses near the Caroni River about $100 \mathrm{~km}$ SE of Ciudad Bolivar, Venezuela, demonstrated a protolith age in excess of $3.4 \mathrm{Ga}$, as well as a possible Late Archaean $(2.7 \mathrm{Ga})$ igneous and metamorphic event prior to the Early Proterozoic (Trans-Amazonian) granulite facies metamorphism. The Complex is also apparently cut by granitoid rocks of Trans-Amazonian age.

\section{Early Proterozoic Greenstone Belts}

The greenstone belts located in the northern and eastern parts of the shield have most of the typical characteristics of their Archaean counterparts elsewhere. The proportions of the various volcanic and sedimentary rocks are similar to those of the Canadian Archaean for example, though they differ from the more mafic to ultramafic Archaean belts of Australia, India and Southern Africa. However, in sharp contrast, the Guiana Shield greenstone belts have TransAmazonian metamorphic ages of 2.0-2.1 Ga, and their apparent protolith ages are also Early Proterozoic.

Zircons derived from volcanic and sedimentary precursors of the Barama-Mazaruni Supergroup in northern Guyana have been dated at 2.25 \pm 0.1 Ga (Gibbs and Olszewski, 1982). Because of their lithological, structural and metamorphic similarities, the various greenstone belts of the Guiana Shield are correlated with one another, and the inference is that all of them will be found to have Early Proterozoic origins. However, both younger (Priem et al., 1980) and older (e.g. Lima et al., 1974) ages have also been invoked on the basis of $\mathrm{Rb}-\mathrm{Sr}$ reference isochrons for the parent rocks of some of these belts.
The greenstone belts consist principally of metabasalts and subordinate metamorphosed andesites, dacites and rhyolites, together with metagreywackes, phyllites and metaconglomerates derived predominantly from the associated volcanics and sediments. Metamorphosed manganiferous and ferruginous sediments, cherts and carbonates are also present.

Metavolcanic rocks with tholeiitic, calc-alkaline, and magnesian series compositions are found in the northern greenstone belts. The magnesian series rocks include highly magnesian basalt flows and conformable ultramafic rocks, now generally talc schists. Many of the volcanic rocks have chemical, mineralogical and textural evidence of spilitic alteration, and pillow structures have been found in many locations. There are also subvolcanic felsic intrusives in many of the belts, revealing the locations of felsic eruptive centers.

The metasediments include many varieties of tuffs, volcaniclastic conglomerates, greywackes and shales derived from the associated volcanics. Turbidite structures and bedsequences indicating submarine fan complexes are common. Cross-bedded conglomerates and sandstones, possibly of braided river facies, have been recorded in several localities. Mudcracks have been observed in northern Guyana, and there are local unconformities, particularly in regions with abundant felsic volcanics and hypabyssal rocks. Carbonate rocks weather readily in the humid tropics, and the only recorded occurrence in the greenstone belts is a carbon-laminated algal(?) limestone from a drill core in central Guyana. Disseminated carbonate is common in many of the rock

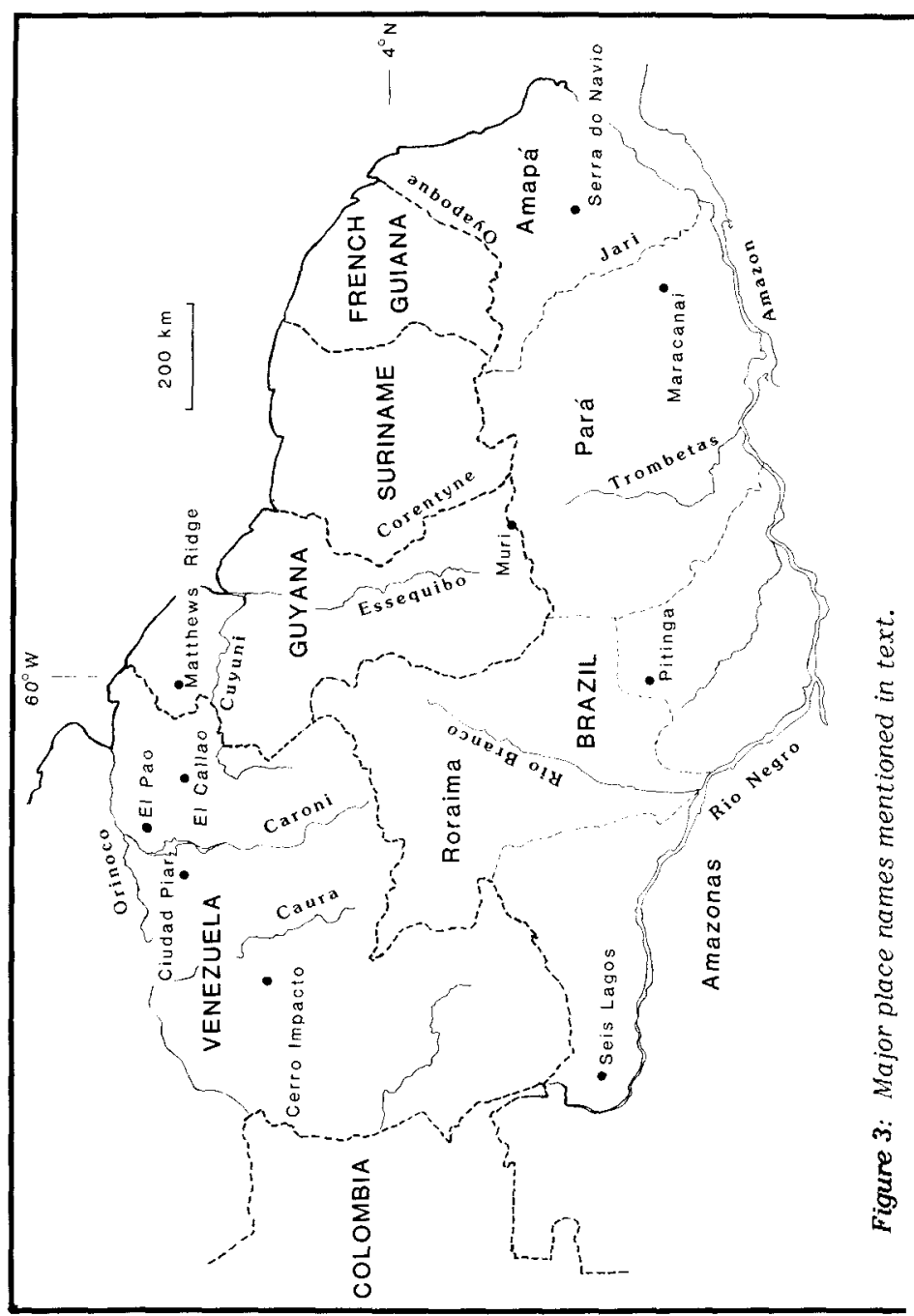


types, however. No indication of a continental source for any of the greenstone belt metasediments has bcen recognized, and no highly mature sediments such as orthoquartzites or arkoses have been noted in them.

Stratigraphic sections have been constructed for some of the northern belts that have relatively moderate deformation (Menendez, 1972: Marot and Capdevila, 1980; Gibbs, 1980). In Guyana the stratigraphic thicknesses of the greenstone belts are estimated at an average of $8-10 \mathrm{~km}$. There is a general and characteristic stratigraphic succession from mafic to felsic volcanic rocks overlain in turn by the sedimentary rocks, though many of these lithologies are also interstratified.

Metamorphism ranges from sub-greenschist to amphibolite facies, with the higher grades generally located on the peripheries of the belts, adjacent to granitoid intrusives and gneisses. There is also a tendency for the older stratigraphic units (metabasalts) to occur in the marginal and the metasedimentary rocks in the central portions of the belts. The nor thern two greenstone regions have rather random, branching synclinal structural styles, while the southeastern belts of Amapá, Brazil, are highly elongated, due to particularly intense late Trans-Amazonian deformation.

\section{Other Trans-Amazonian Metamorphic and Granitoid Rocks}

In the basement to the platform-cover terrane in the central part of the shield, there are exposures of supracrustal rocks that were metamorphosed to medium and high grades during the Trans-Amazonian. These include the Parima and Cauarane Groups in Brazil, the Kwitaro Group in southern Guyana, and the Coeroeni and Falawatra Groups in Suriname (Table 1).

The protoliths of these metamorphic rocks include pelitic sediments, orthoquartzites, iron formations, carbonates and volcanic rocks. However correlations between these units have not been fully resolved, and it is unclear to what extent any of them can be linked with the greenstone belts to the north and east. The presence of mature, platform-type sediments indicates that at least some of these groups were deposited on continental crust, possibly in an intracratonic (Kroonenberg, 1976) or continental-marginal setting.

Extensive areas of gneisses, amphibolites, granulites and calc-alkaline granitoid intrusives make up the remainder of the granite-greenstone terranes. They form the basement to the platform-cover assemblages in the central and western parts of the shield. Indeed, the metamorphism and deformation of the basement rocks and the intrusion of granitoid rocks are the most significant manifestations of the TransAmazonian Orogeny. In most instances, there is general conformity in structure between the gneisses and the adjacent greenstone belts, though granitoid intrusives and faults commonly disrupt the contacts.

The ages and stratigraphic significance of the parent rocks to the gneisses and the granulites are controversial. On the basis of comparisons with the Imataca Complex and some reported isotopic ages in excess of $2.5 \mathrm{Ga}$, these high-grade rocks have often been considered Archaean basement to the Early Proterozoic rocks (e.g. Martin, 1974; Cordani et al., 1979; Lima et al., 1982). However, this is unlikely to be true of most of the gneisses and granulites for several reasons.

First, the geochronological evidence for Archaean ages in the gneisses or granulites is sparse and inconclusive. U-Pb dates on zircons provide the most reliable data, and for the gneisses of the northern half of the shield these range from about $2.25 \mathrm{Ga}$ (approximately coeval with the greenstone belt volcanism) to $2.05 \mathrm{Ga}$ in the Trans-Amazonian range (Gibbs and Olszewski, 1982; Priem and others, 1978).

Second, on the basis of their field relations, chemistry and petrology, the high- and medium-grade Trans-Amazonian metamorphic rocks could have been derived from the same

volcanic and sedimentary strata that appear at lower metamorphic grades in the adjacent greenstone belts (Cannon, 1964; Jorge João and Marinho, 1982) or at medium grade in the metasupracrustal groups of southern Guyana and western Suriname (Kroonenberg, 1976). Finally, as indicated earlier, the greenstone belts appear to have bcen formed in an ensimatic environment, without underlying or adjacent continental crust. Nevertheless, considering the vast region involved, the complexity of the rocks and the relatively sparse geochronological and petrological data available, the possibility of Archaean precursors somewhere in these TransAmazonian rocks cannot be denied.

Trans-Amazonian granitoid intrusives are extensive and complex, and only a few have been carefully examined. Most are of calc-alkaline affinity, including gabbro, diorite, quart? monzonite, sodic tonalite and adamellite. In some there is a sequence of intrusion from early mafic to later felsic com-

Table 1. Major Precambrian units and events of the Guiana Shield.

Key to localities: V - Venezuela, G - Guyana, S - Suriname, F French Guiana, B - Brazil, C - Colombia; $c$ - central, n -northern, e - eastern, 5 - southern, w - western portions of the shield within the various countries. Boundary between Early and Middle Proterozoic taken as $1.9 \mathrm{Ga}$.

\section{LATE PROTEROZOIC}

Tectonothermal

events

$(1.3-0.9 \mathrm{Ga})$

Alkaline complexes:

(ages uncertain)

Nikerie metamorphism, K'Mudku mylonites, Jari-Falsino and Orinoquan events

Cerro Impacto (cV), Muri Mountains $(\mathrm{sG}, \mathrm{nB})$, Seis Lagos? (wB), Maracanai? (sB)

Volcanics: Seringa Frr. (sB), Piraparana Fm.(C)

\section{MIDDLE PROTEROZOIC}

Parguazan granites: (1.55-1.45 Ga)

Mafic intrusives: $(1.7-1.5 \mathrm{Ga})$

Sedimentary rocks: (1.65-1.75 Ga)

Felsic volcanics $(1.75-1.90 \mathrm{Ga})$

and associated granites:

Pre-Uatumã sedimentary rocks:

Parguaza (wV), Surucucus $(n B)$, Abonari (sB), Tiquić (wB)

Avanavero Suite (V, G, S, B), Quarenta Ilhas (sB), Pedra Preta (nB)

Roraima Gp. (V, G, S, B), Urupi Fm. (sB)

Uatumã Supergroup (V, G, S, B): Cuchivero (V), Burro-Burro and Kuyuwini Gps. (G), Dalbana Fm. (S), Surumu Frn. (nB), Iricoume Fm. (sB)

Cuchivero (nV), Saracura (nB), Mapuera $(s B)$

Muruwa Fm. (cG), Ston Fm. (wS), Tunui Gp.? (wB), Cinaruco Fm.? (wV), Los Caribes Fm.? (cV), La Pedrera Fm.? (C), La Ouina Fm.? (wV)

\section{EARLY PROTEROZOIC}

Trans-Amazonian

granites:

$(2.05-2.15 \mathrm{Ga})$

Trans-Amazonian mafic intrusives:

Trans-Amazonian metamorphic

complexes:

Greenstone belts: (2.25 Gia)

Other metasupracrustal units
South Savanna (sG), Kartabu (cG), Gran Rio (5), Agua Branca (sB)

Tapuruquara Suite (cB) Appinitic Suite ( $5 G$ ), De Goeje Suite (S), San Juan de Manapjare (sV)

Ile de Cayenne (F), Supamo (CV), Bartica (cG), Kanuku (sG), Guianense Complex (B), Mitu Complex? (C),

Pastora Sgp. (V), Barama-Mazaruni Sgp. (G), Marowijne Gp. (S), Paramacca Sgp. (F), Vila Nova (eB)

Coeroeni and Fallawatra Gps. (S), Cauarane ( $\mathrm{B}$ ), Kwitaro and Kanuku Gps. $\left(\mathrm{sG}_{\mathrm{G}}\right.$, Parima Gp. (nB)

\section{ARCHAEAN}

La Ceiba migmatite $(n \vee) 2.7$ Ga

Gurian Orogeny (pre 3.0 Ga)

Imatara Complex (nv) (pre-3.5 Ga protolith) 
positions. There are also two-mica and biotite granites that are closcly associaled with metasediment5, particularly within the northermmost grcenstone belts, and that are probably of anatectic. "S-type" origin. Many of the granitoid intrusives are foliated, particularly near their margins.

There are scveral groups of relatively small mafic to ultramafic intrusions that are thought to have intruded late in the Trans-Anazonian cycle, because of their ficld relations and apparent Trans-Amazonian metamorphism (sce Table 1). There is also a large meta-anorthosite in the Kaburi River valley of northern Guyana that may be part of a differentiatcd intrusive complex.

In some areas there was considerabic late Trans-Amayonian cataclasis that affected the metamorphosed greenstoncs and gneisses, as well as many of the granitoid rocks. Nearly all of the rocks of $\triangle$ mapá and northeastern Pará, Brazil, show a strong $\mathrm{NW}$ elongation due to this event. Similar elongation and catarlasis, though not as extreme, orcur approxinately along strike in central and western Guyana and in northcontral Brazil. An ENE-striking structural grain can be traced from the contral Roraima Terrjtory (Brazil), through southern Guyana and into western Suriname. Major faults with this ENE orientation have been mapped in the Kanuku Mountains in Guyana, the Bakbuys Mountains in Suriname and at the boundary between the Imataca Complex and the rest of the shield in Venczuela. These are the youngest recognizable features of the Trans-Amazonian Orogeny, and they affected continental crust that was already rclatively coherent and consolidated. A period of stability, erosion and crustal extension over much of the shicid followed.

\section{Middle Proterozoic -}

\section{Continental Sedimentation and Anorogenic Magmatism}

Between about 1.9 and $1.5 \mathrm{Ga}$, continental sediments and volcanic rocks were deposited and associated granites intrudcd over much of the central and western portions of the Guiana Shield. They do not, however, extend far into the grcenstone regions to the north and east (Fig. 4). This geographir scparation into plattorm cover and greenstonc regions can be traced without significant offset into the Guaporé Shield to the south of the Amazon (Fig. 2).

The various groups of Middle Proterozoic sediments and volcanics rescmble one another lithologically, and they are profoundly unconformable on the Trans-Amazonian rocks, showing nonc of the late Trans-Amazonian cataclasis. The onset of their deposition forms a suitable marker for the beginning of the Middle Proterozoic in the shicld (Santos, 1978). There was a long period (from about 1.9 to $1.5 \mathrm{Ga}$ ) during which the continental surface was exposed to erosion, weathering and sedimentary reworking to producc mature clastic sediments. Predominantly felsic igneous rocks with calc-alkaline to alkaline compositions were crupted and intruded during several major episodes (see Table 1), and mafic dikes and sills were intruded in the 1.7-1.5 Ga interval.

The oldest Middle Proterozoic rocks are mature sandstones, conglomerates and shales. The best example is the Muruwa Formation of central Guyana, which conformably overlies the Barama-Mazaruni Supcrgroup of the greenstone belts and is in turn conformably overlain by the Iwokrama Formation of the L'atuma Supergroup. Most of the pre-Uatumã units listed in Table 1 lithologically resemble the Roraima Group and have previously been correlated with it, but the Roraima Group overlies the Ijatuma Supergroup with substantial unconformity in most places.

The latuma Supergroup volcanics and their associated granites are the most extensive of the Middle Proterozoic units The Uatumã includes flows, subordinate crystal and crystallithic tuffs, and coarser-grained pyroclastic rocks. Santos (1982) has demonstrated the presence of both calc-alkaline (andesite through rhyolite) and alkaline (trachyte, latite, alkali rhyolite) compositional trends. The associated intru- sive rocks include granite, granophyre, adamellite, granodiorite, and minor quartz diorite and guart\% sycnite. These have becn dated between 1.7 and 1.9 Cia by both Rb-Sr and $\mathrm{K}-\mathrm{Ar}$ methods, and they have initial ${ }^{87} \mathrm{Sr} /{ }^{85} \mathrm{Sr}$ ratios typically grcater than 0.704 , with many over 0.796 (c.g. Priem et al. 1970; Snelling and Rerrangé. 1970; Bisei and Teixeira, 1975 . Gaucicte et al., 1978). Such ratios indicate that older continental crust was probably incorporated in the melts.

Most of the Middle Proterozoic scdimentary and voleanic rocks arc undeformed or stow localized delormation related to block faulting or to tije associated mafjc and felsic intrusions. Fixcept in intrusive contact aurcoles their metamorphism is generally of sub-grecnschist faries. The sedimentary and igneous rorks and their styles of deformation demonstrate the prevalence of crustal extension during this period.

In the regions with Middle Proterozoic platform cover, the Trans-Amazonian basement consists predominantly of medium to high-grade metamorphir rorks and granites. It is possible therefore that the crust in these regions was eroded to decper levels than the crust along the Atlantic margin where lower grade Trans-Amazonian rocks are common. This interpretation is consistent with the suggestion that the Middle Proterozoir rocks are the products of an extensional tertonic proress which involved doming in its early stages.

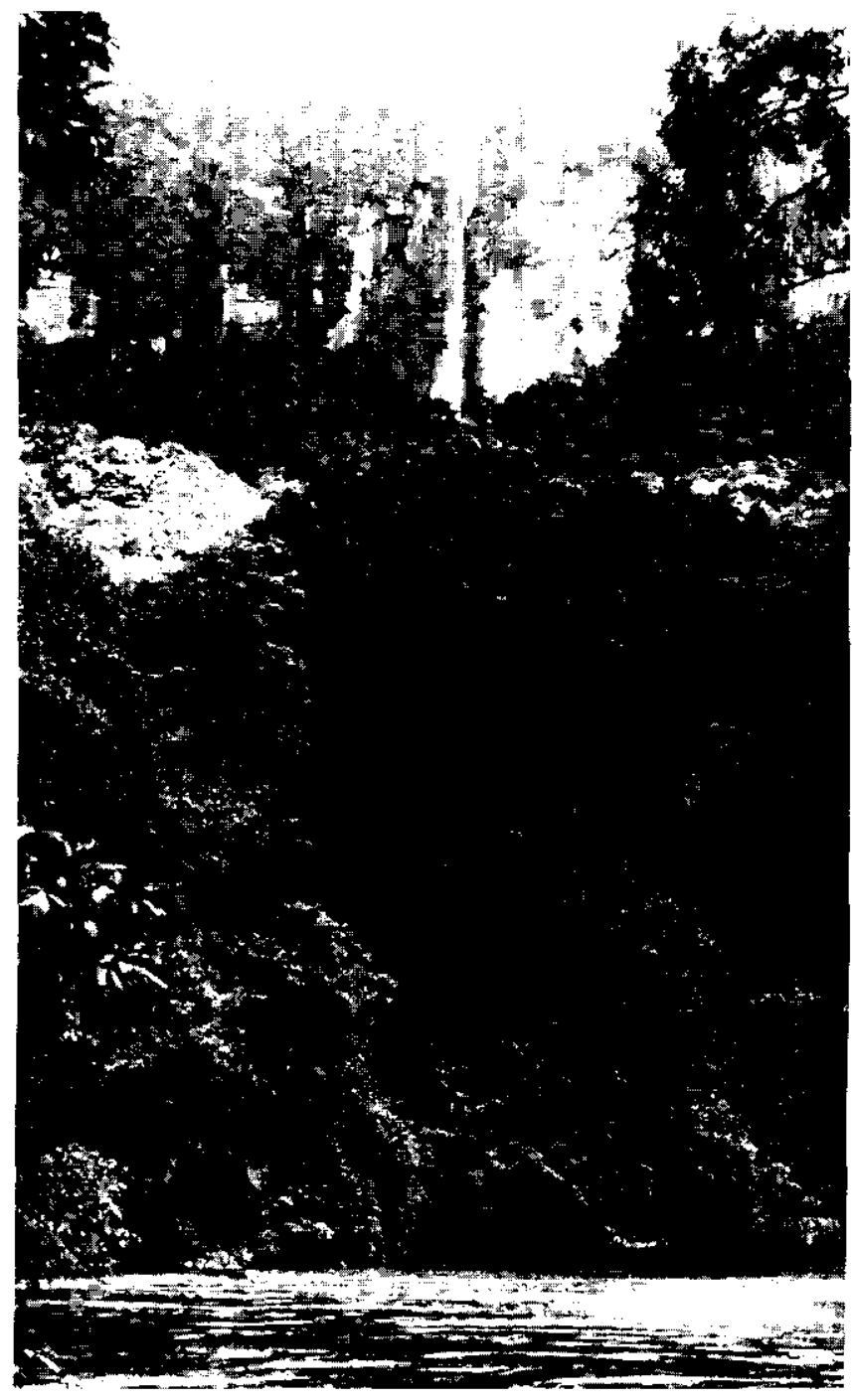

Figure 5: Waterfall over Roraima Formation escarpment on the Meamu River of western Guyana. 


\section{The Roraima Group and Associated Intrusives}

The Roraima Group includes most of the Middle Proterozoic sedimentary rocks that unconformably overlie the Uatumã Supergroup. These sediments are typically exposed as mesas, with gentle dips except near to block faults or intrusives (Fig. 5). The Group reaches a thickness of about $2.5 \mathrm{~km}$ at Mount Roraima, which forms a common boundary point of Guyana, Venezuela, and Brazil (see cover photo). The Roraima Group occurs over a total area $1000 \mathrm{~km}(\mathrm{E}-\mathrm{W})$ by $600 \mathrm{~km}(\mathrm{~N}-\mathrm{S})$. The largest block forms the Pakaraima Mountains, covering about $73000 \mathrm{~km}^{2}$ in Guyana, Venezuela and Brazil, and other blocks are present in northwestern Brazil, southern Venezuela and Suriname.

The Roraima Group includes or thoquartzites, arkoses, conglomerates, minor shales and jasperoid tuffs deposited in fluvio-deltaic and lacustrine environments (Reid, 1972; Keats, 1974). Most of the clasts in the conglomerates are quartz pebbles and reworked sandstones, products of extended weathering and repeated reworking of the surrounding Trans-Amazonian basement and cover rocks. Age determinations on jaspery ash tuffs interbedded with sandstones of the Roraima Group in Venezuela and Suriname are $1.73 \mathrm{Ga}$ (Gaudette and Olszewski, 1981) and $1.65 \mathrm{Ga}$ (Priem et al., 1973) respectively.

The Roraima Group in the Pakaraima basin appears to have been fault-bounded. Its present erosional escarpment in Guyana is not far from the original depositional edge of the basin, judging from the increase in thickness of its conglomeratic members in this direction (Keats, 1974). At least one fault, the Tumatumari Fault of central Guyana, is known to have originated during or just prior to the Roraima Group deposition.

Minor felsic intrusives occur in the lower part of the Roraima Group in Guyana, possibly associated with volcanism that produced the jaspery tuffs. Dikes and extensive sills of the Avanavero Suite of continental tholeiites cut the Roraima Group and extend across most of the Trans-Amazonian basement of the northern part of the shield. The most prominent Avanavero Suite exposures, however, are sills in the Roraima Group (hence their previous name "Roraima Intrusive Suite"). Hebeda and others (1973) have dated Avanavero dolerites in western Suriname at $1.64 \mathrm{Ga}$.

Similar mafic intrusives, the Quarenta Ilhas Suite, cut the Urupi Formation in the southern part of the shield. The

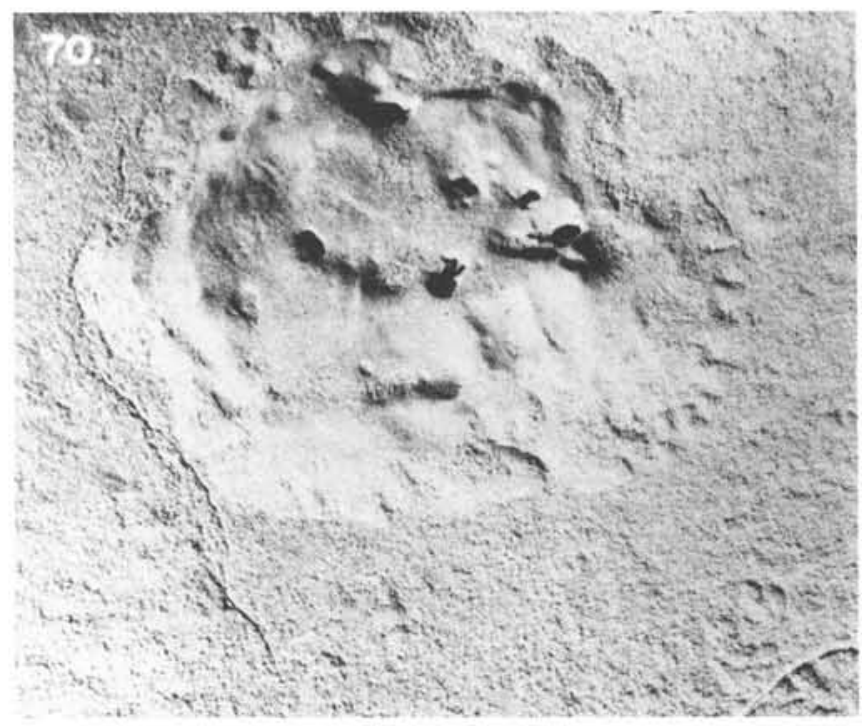

Figure 6: Air photo of the Seis Lagos alkaline complex of western Brazil. The hilly lateritic terrain with many lakes is about $5 \mathrm{~km} \mathrm{~N}-\mathrm{S}$.
Urupi Formation, a much smaller but similar unit, overlies Uatumã Supergroup rocks in the south-central part of the shield, and similar units of approximately the same age occur extensively south of the Amazon Basin.

\section{The Parguazan Episode}

Reconnaissance geochronology in the western part of the Guiana Shield has revealed widespread anorogenic granitoid intrusion and metamorphism between 1.56 and $1.45 \mathrm{Ga}$ (Pinheiro et al., 1976; Gaudette et al., 1978; Priem et al., 1982). This is the youngest of the major anorogenic granitoid episodes of the shield. The Parguaza batholith of Venezuela is the largest of this series of granites, many of which have rapakivi textures. Dall'Agnol (1982) has compared these granites with Phanerozoic "younger granites" of West Africa.

The significance of the concentration of Middle Proterozoic ages in the western part of the shield is controversial. Cordani et al. (1979) distinguish a separate Rio NegroJuruena Province which they consider to consist predominantly of material accreted to the continental crust at that time. Priem et al. (1982) have provided evidence that the Middle Proterozoic events principally involved reworking of Trans-Amazonian basement.

\section{Late Proterozoic Events:}

During the period 1.3 to $1.0 \mathrm{Ga}$, the western, southern and eastern margins of the Guaporé Shield and the western margin of the Guiana Shield were affected by high-grade metamorphism, folding and igneous intrusion. These events include the Sunsas Orogenic Cycle of the Guapore Shield (Berrangé, 1982) and the formation of a granulite belt in the Colombian Andes (Kroonenberg, 1982). The Paraguai-Araguaia fold belt of the late Precambrian Brazilian Orogenic Cycle forms the southern and eastern margins of the Guapore Shield and projects beneath the Amazon Basin to the east of the Guiana Shield.

Within the Guiana Shield there is evidence of Late Proterozoic faulting, resetting or closure of isotopic systems in micas, and igneous intrusion, possibly associated with the more intense activities on the periphery of the Shield. Most of these faults are oriented northeasterly and are associated with mylonites and pseudotachylites along the southern boundary of the Imataca Complex, along the Kanaku and Bakhuys Mountains, and in Amapá. These have been referred to as the Orinoquan, the K'Mudku and the Jari-Falsino Events respectively. It is likely that this late Proterozoic faulting involves substantial reactivation of older zones of weakness.

$\mathrm{Rb}-\mathrm{Sr}$ and $\mathrm{K}$-Ar ages of micas obtained over much of the shield in the range 1.3-1.0 Ga are taken as evidence of the Nickerie metamorphism. It is not known, however, to what extent this event represents a discrete thermal pulse or simply crustal uplift with subsequent cooling and closure of isotopic systems.

The late Proterczoic igneous events include intrusion of alkaline complexes and mafic and felsic volcanics. Alkaline complexes have now been discovered in widely scattered parts of the shield, through their circular appearance on radar imagery and air photos (Fig. 6). Those listed on Table 1 are thought to include carbonatites, because of the exotic mineralogies and compositions of their weathered exposures. Drilling efforts to date have, however, generally been unable to penetrate beneath their thick lateritic caps.

Alkaline basalts of the Seringa Formation dated at about 1.15 $\mathrm{Ga}$ overlie the Urupi Formation in the south-central part of the shield, and Priem et al. (1982) have obtained a date of $0.92 \mathrm{Ga}$ on felsic volcanics in southeastern Colombia. These are the youngest known Precambrian volcanic rocks.

\section{Post-Precambrian Events:}

The most important Phanerozoic events affecting the Guiana Shield were Palaeozoic and Mesozoic dike intrusions and the crustal uplifts and depressions that formed the present moun- 
tain ranges and sedimentary basins. The Kanuku and Bakhuys Mountains of Guyana and Suriname respectively are faulted blocks of high-grade metamorphic rocks. The Takutu Graben adjacent to the Kanuku Mountains is filled with Mesozoic sedimentary and volcanic rocks, and there may be a corresponding graben beneath the Quaternary cover along the Rio Branco. Together with the Berbice coastal basin in eastern Guyana, these grabens nearly divide the shield into two separate lobes. Mesozoic dikes are particularly common along this Rio Branco-Berbice basin axis and in eastern Amapá where they parallel the coast (Fig. 7). The grabens and dike intrusions are thought to have originated during the opening of the Atlantic and may have reactivated older Proterozoic structures (McConnell, 1969).

The Amazon Basin does not significantly offset the geologic pattern between the Guiana and Guapore Shields, and correlations from one to the other are remarkably clear. Geophysical data indicate that the core of the Amazon Basin probably has a graben structure. However, no major faults have been mapped in the exposed Palaeozoic strata or basement near its margins, although Mesozoic diabase sills and dikes are locally present along the northern margins of the basin (Fig. 7).

The base of the Roraima Group in the Pakaraima Mountains, like that of many of its outliers, is now close to the present sea level, as a result of regional uplift in the Mesozoic and Tertiary. However, separate fault-bounded uplift of the Pakaraima block is not indicated, for the Avanavero Suite dikes and inclined sills have not been notably offset between the Roraima Group and the neighbouring areas of older basement. A moderate epeirogenic uplift is thus characteristic of the entire Amazonian Platform, including the Amazon Basin where Palaeozoic marine strata are now exposed.

\section{Economic Geology and Mineral Potential}

The major ore deposits of the shield include iron at the $\mathrm{El}$ Pao and Cerro Bolivar mines in the Imataca Complex and manganese at the Serra do Navio and now inactive Mat thews Ridge mines in the greenstone belts. Major placer and eluvial gold deposits have long been worked by hand and dredge. There are numerous shallow gold mines in the greenstone belts and granites, but the only deep gold mine is the $\mathrm{El}$ Callao mine in Venezuela.

Tin has been mined from placers and veins in Amapá, and a new mine at Pitinga, nor th of Manaus, is producing tin that is regionally associated with granites of the Parguazan cycle. Columbite-tantalite has been produced from pegmatites in some of the Trans-Amazonian granites in Guyana, and columbite-tantalite and tin have been mined on small scales from placers in French Guiana and Suriname. Molybdenite mineralization associated with granitoid intrusives of several ages has been found in Guyana and Brazil.

There have been numerous uranium exploration efforts, many of them focused on regions with Middle Proterozoic sedimentary rocks. Occurrences of uranium mineralization have been found in association with pegmatites and alkaline complexes as well.

Diamonds have been produced from placer workings all around the Pakaraima Mountains. They are generally regarded as derived from pre-Roraima kimberlites preserved in the conglomerates of the Roraima Group. Several active exploration projects are now searching for diamantiferous kimberlites. Bauxite deposits are developed on weathered Precambrian rocks in Guyana and Venezuela, in coastal sediments in Suriname and along the Trombetas River near the Amazon. Kaolin and high-purity sand deposits are also present in weathering zones and in the Mesozoic-Cenozoic sedimentary cover.

Most of the important ore deposits cited above are products of, or have been significantly enriched by the tropical weathering. Though hardly tapped as yet, the mineral resources of the bedrock are likely to be economically important in the future, for they probably include base metals, gold, tin, diamonds, uranium and carbonatite-related ores.

Massive base metal sulphide deposits are probably present in the greenstone belts, based on an analogy with the Canadian Archaean belts and on correlation with the Grão Para Group greenstone belts of the Serra dos Carajás region in the Guaporé Shield. The Carajás region has been the site of major iron, copper, gold, manganese and nickel discoveries, all except the iron being found within the past few years. occurrences of favourable lithologies, characteristic hydrothermal alteration and sulphide mineralization are known in most of the Guiana Shield greenstone belts as well, though no major ore deposits of this type have been reported yet.

\section{Some Important Geological Problems}

Much progress has been made in recent years in establishing the lithostratigraphy and structure of the various greenstone belts of the Guiana Shield. It should now be possible to study the regional differences in stratigraphy, volcanic compositions and age in order to understand better the genesis of these belts and to see what they will reveal about crust and upper mantle processes in the Early Proterozoic. There are, for example, obvious analogies with both Archaean greenstone belts and with Phanerozoic subduction complexes particularly island arcs.

The similarities between the Guyana and West African Precambrian have long been apparent and have been described by McConnell (1969), Choubert (1974) and Martin (1974) aniong others. The early Proterozoic greenstone belts of the Guiana Shield are comparable in age and lithologic diversity with the type I Birrimian belts of the Man Shield of southern West Africa (Black, 1980). The type II Birrimian belts as described by Black have more in common with the metasedimentary belts of the central part of the Guiana Shield than with the greenstone belts. The Eburnian Orogeny is similar to the Trans-Amazonian in age and metamorphic and igneous style, but there appears to be no major counterpart in the Guiana Shield to the Pan-African events of the latest Proterozoic and early Palaeozoic. The Tarkwian metasediments of West Africa, important for their palaeoplacer gold, might be broadly correlated with the pre-Uatumã metasedimentary rock of the Guiana Shield but the Tarkwian rocks are more $60 \mathrm{~W}$

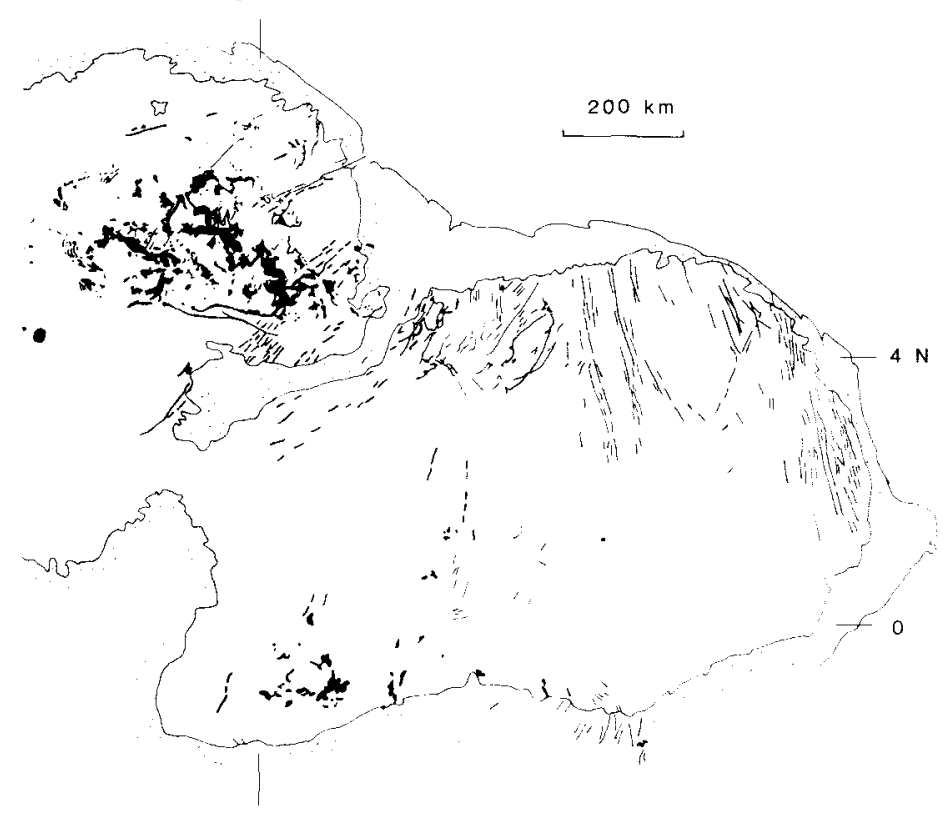

Figure 7: Dikes and sills of the Avanavero, Quarenta Ihas and Pedra Preta Suites (Middle Proterozoic), and the flows of the Seringa Formation (Late Proterozoic). 
intensively deformed. The extensive Uatumã Supergroup and Roraima Group are absent from the Atlantic margin of the Guiana Shield and have no major correlatives in West Africa.

The development of extensive felsic volcanics and granitoids relatively soon after the consolidation of continental crust is not unique to the Guiana Shield, but this must rank as one of the prime examples of such phenomena. There are ample exposures over vast regions of northern South America, making this a good place to study the processes involved in their development. The cause of this anorogenic magmatism is not well established, and the relationship needs to be resolved between these rocks and the preceding TransAmazonian episode, as well as the contemporaneous orogenic events in the southwestern part of the Amazon platform.

Several aspects of the present synopsis are particularly controversial and require further confirmation. Is Archaean crustal material entirely absent from the Trans-Amazonian metamorphic terranes? How do the metamorphosed supracrustals in the central portion of the shield correlate with one another, and what is their relationship to the northern and eastern greenstone belts? Are the Early Proterozoic rocks and events completely separate from those of the Middle Proterozoic, or are they part of a single orogenic cycle? The new IGCP Project 204 on "The Precambrian Evolution of the Amazonian Region" will undoubtedly help to resolve these issues.
ABOUT THE AUTHORS:

Allan Gibbs is an assistant professor at Cornell University (Dept. of Geological Sciences, Kimball Hall, Ithaca, NY 14853 , U.S.A.), with teaching and research interests in Precambrian and economic geology. He worked with the Guyana Geological Survey for about five years, concentrating on the geology of the greenstone belts and the development of exploration geochemical methods suitable for the tropical rainforest environments.

Christopher Barron has worked with the Guyana Geological Survey (Geology and Mines Commission, Box 1028, Georgetown, Guyana) since 1954, and has conducted fieldwork in most parts of the country including several recent expeditions to the Muri Mountains alkaline complex. He has taught geology and geomorphology at the University of Guyana and is now working on a new geological map of Guyana. Barron and Gibbs are currently writing a book on the geology of the Guiana Shield.
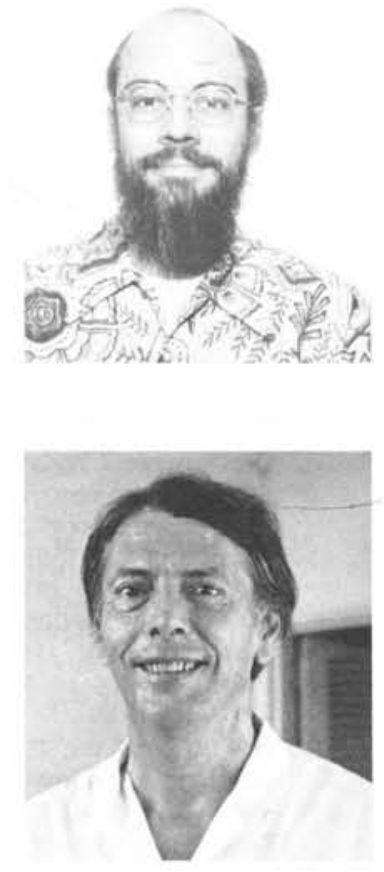

Acknowledgements

Many more works than can be properly cited here have been mportant in the development of our interpretations of the regional geology. Some of the individuals and organizations that have generously helped us with up-to-date material and explanations are Manaus, Brazil), Xafi Jorge Jošo (C.P.R.M.. Belem, Brazil). Alain Marot (Braz.G.M., Cayenne. French Guiana), Robert de Vletter (Suriname Geology and Mining Service). Nesin Benaim (Direccion Geologia, Venezuela), Alirio Bellizzia (Lagoven, Caracas, Venezuela), Henry Briceño (Universidad Central, Caracas, Venezuela), Umberto Cordani and Wilson Teixeira (Universidade S\$̃o Paulo. Brazill), and Salomon Kroonenberg (formerly Centro Interamericano berg, K. Attoh and F.F.M. de Almeida are also gratefully acknowledged.

\section{References}

Inonymous, 1977. Geological Map of Suriname, 1:500000. Geologisch Mijnbouwkundige Dienst, Suriname.

Ascanio, T.G., 1975. El Complejo de Imataca en los alrededores de Cerro Bolivar, Estado Bolivar, Venezuela. Anais I0th. Conferencia Geologica Interguianas, Belem Brasil, Departamento Nacional da Produção Mineral, p. 181-197.

Basei, M.A. and Teixeira, W., 1975. Geochronologia do Territorio de Roraima. Anais 10th Confencia Geologica Interguiaras. Belém, Brasil, Departamento Nacional da Produção Mineral, p. 453-473.

Bellizzia, A., Garcia, R., Ramirez, C., Gonzalez, L.A., Espejo, A., Campos, V., Rios, J.H., Mendoza, V. and Benaim, N., 1976. Mapa Geologico Estructural de

Berrange, J.P., 1977. The geology of southern Guyana, South America. Institute of Geological Sciences, London, Overseas Division Memoir 4, $112 \mathrm{p}$

Berrangć, J.P., 1982. The eastern Bolivia mineral exploration projec.

Black, R., 1980. Precambrian of West Atrica. Episodes, v. 1980 no. 4, p. 3-8.

Bosma, W., Kroonenberg, 5.B., van Lisa, R.V., Maas, K. and de Roever, E.W.F., in preparation. Explanation of the geological Map of Suriname, Explanation. Int de Vletter, D.R. (ed.), The Geology of Suriname, Geologisch Mijnbouwkundige Dienst Sur.name, Mededeling 27.

Cannon, R.T., 1964. The geology of the Bartica Assemblage. Geological Survey British Guiana Bulletin v. 35, 83p.

Choubert, B., 1974. Les precambriens des Guyanes. Memoir Bureau de Recherches Geologues et Miniéres No. 81 , $213 \mathrm{p}$.

Cordani, U.G., Tassinari, C.C.G., Teixeira, W., Basei, M.A.S. and Kawashita, K., 1979. Evolução tectonica da Amazonia corr base nos dados geocronologicos. Segundo Congreso Geologico base nos dados geocronologicos. Segundo Congreso
Chileno, Arica, Chile, Aug. 6-11, 1979, p. 3137-3148.

Dall'Agnol, R., 1982. Os granitos anorogenicos da Amazonia Brasileira: suas analogias com os "younger granites" do oeste da Africa. Actas 5th Congreso Latino Americano de Geologia, Argentina 1982, II, p. 113-131.

Dougan, T., 1977. The Imataca Complex near Cerro Bolivar, Venezuela - a calc-alkaline Archean Protolith. Precambrian
Rescarch, y, 4. p. 237-268.

Gaudette, H.E., Mendoza, V., Hurley, P.M. and Fairbairn, H.W, 1978. Geology and age of the Parguaza rapakivi granite, Venezuela. Geological Society of America Bulletin, v. 89, p. $1335-1340$.

Gaudette, H.E. and Oszewski, W.J., 1981. Geochronology of the basement rocks, Amazonas Territory, Venezuela (abs.). Resimenes, Simposium Amazonico, Puerto Auyacucho, Venezuela,
22-27 March 1981, p. 24-25.

Cibbs, A.K., 1980. Geology of the Barama-Mazaruni Supergroup of Guyana. Harvard University Ph.D. Dissertation, University Microfilms International, Ann Arbor, Michigan, 446p.

Gibbs, A.K. and Olszewski, W.J., Jr., 1982. Zircon U-Pb ages of Guyana greenstone-gneiss terrane. Precambrian Research, y. 17. p. 199-214.

Hebeda, E.H., Boelrijk, N.A.t.M., Priem, H.N.A., Verdurmen, E.A. and Verschure, R.H., 1973. Excess radiogenic argon in the Precambrian Avanavero dolerite in western Surin
and Planetary Sciance Letters, v. 20, p. 189-200.

Jorge Joฐ̃o, X. and Marinho, P.A., 1982. Catametamorfitos Arqueanos da regiáo centro leste do Teritório Federal do Amapá. In: Anais do I Simposio de Geologia da Amazonia, Belém, Sociedade Brasileira de Geologia, Núcleo Norte, v. 2, p. 207-228.

Keats, W., 1974. The Roraima Formation in Guyana: a revised stratigraphy and a proposed environment of deposition. Memoria 2nd Congreso Latinoamericano de Geologia, Caracas, 1973.
Venezuela Ministerio de Minas e Hidrocarburos, Boletin de Venezuela Ministerio de Minas e Hidrocarburos, Bos
Geologia, Publicacion Especial No. 7, v. 2, p. 901-940.

Kroonenberg, S.B., 1976. Amphibolite-facies and granulite-facies metamorphism in the Coeroeni-Lucie area, southwestern Suriname. Geologische Mijnbouwkundige Dienst Suriname, Mededeling 25, p. 109-289.

Kroonenberg, S.B., 1982. A Grenvillian granulite beit in the Colombian Andes and its relation to the Guiana Shield: Geologie en Mijnbouw, v. 61, p. 325-333.

Lima, M.I.C. et al., 1974. Geologia. In: Brasil, Departamento Nacional da Produção Mineral, Projeto RADAMBRASIL, Foltha
NA/NB.22, Macapa, Levantamento de Recursos Naturais, v. 6.. $120 \mathrm{p}$.

Lima, M.I.C., de Oliveira, E.P. and Tassinari, C.C.C., 1982. Cinturoes granuliticos da porçao setentrional do craton Amazonico. Anais do I Simposio de Geologia da Amazonia, Belém, Sociedade Brasileira de Geologia, Núcleo Norte, v. I, p. 147-162.

Marot, A. and Capdevila, R., 1980. Geologie du synclinorium du sud de Guyane Francaise (abstract). 9th Caribbean Geological Conference, Dominican Republic.

Martin, C., 1974. Paleotectonica del Escudo de Guayana; Memoria 9 th Conferencia Geologica Inter-Guayanas, Puer to Ordaz, 1972 Geologia, Publicacion Expecial No. 6, Hidrocarbur, 251-305.

McConnell, R.B., 1969. Fundamental fault zones in the Guiana and West African Shields in relation to presumed axes of Atlantic spreading. Gcological Society of America Bulletin, v. 80 , p. $1775-1782$

endoza, V., 1974. Evolucion tectonica del Escudo de Guyana. 2nd Congreso Latinoamericano de Geologia, Caracas. Venezue
Menendez, A., 1972. Geologica de la region de Guasipati, Guayana Venezolana. Proceedings of IV Congreso Geologico Venezolano, p. $2001-2046$

Montalvão, R.M.G. de, et al., 1975. Geologia. In: Brasil, Departa. mento Nacional da Produção Mineral, Projeto RADAMBRASit, Folha NA.20, Boa Vista e Parte das Folhas NA.21, TumucuNaturais, v. 8, p. 13-136.

Montgomery, C. and Hurley, P.M. 1978. Total-rock U-Pb and Rb. So Systematics in the Imataca Series, Guyam Shield, Venuzuela Sr Systematics in the Imataca Series, Guyana Shield, Ve
Earth and Planetary Science Letters, v, 39, p. 281-290.

Oliveria, A. da S. et al., 1975. Geologia. In: Brasil, Departamento da Produção Mineral, Projeto RADĀBRASIL, Fotha NA.21, Tumucumaque e parte da Folh
sos Naturais, v, 9, p. 17-118.

Pinheiro, S. da S. et al., 1976. Geologia. In: Brasil, Departamento Nacional da Produçẫo Mineral, Projeto RADAMBRASIL, Folha NA.19, Pico da Neblina, Levantamento de Recursos Naturais, v. il. p. $17-138$.

Priem, H.N.A. et al., 1970. Isotopic geochronology in Suriname. Proceedings 8 th Guiana Geological Conference, Georgetown, 1969. Guyana, Geological Survey Department Paper 3, 30p.

Priem, H.N.A. et al., 1973. Age of the Precambrian Roraima Formation in nor theastern South America: evidence from isotopic dating of Roraima pyroclastic volcanic rocks in Suriname.
Geological Society of America Bulletin, v. 84, p. 1677-1684.

Priem, H.N.A. et al., 1978. How old are the supposedly-Archean charnockitic granulites in the Guiana Shield basement of western Suriname (south America)? In: Zartman, R.E. (ed.), Short Paper 4th International Conference on Geochronology, Cosmochronology, Isotope Geology, 1978,
File Report 78-701, p. 341-343.

Priem, H.N.A., de Roever, E.W.F. and Bosma, W., 1980. A note on the age of the Paramaka metavolcanics in northeastern Suriname. Geologische Mijnbouwkundige, v. 59, p. 171-173.

Priem, H.N.A. et al., 1982. Geochronology of the Precambrian in the Amazonas region of southeastern Colombia (western Guiana Shield). Geologie en Mijnbouw, v. 61, p. 229-242.

Reid, A.R., 1972. Stratigraphy of the type area of the Roraima group, Venezuela. Memoria 9th Conferencia Geologica InterHidrocarburos, Direccion Geologia Publicacion Especial No. 6, p. 343-353.

Santos, J.0.S., 1978. Subdivisao do Pré-Cambriano da Amazonia: uma sugestao. Acta Amazonica, v. 8, p. 267-287.

Santo5, J.O.S., 1982. Granitos Proterozoicos da Plataforma Amazonica, Brasil. Actas Sth Congreso Latinoamericano de Geo. logia, Argentina, v. 2, p. 97-112.

chobbenhaus, C., Campos, D. de A., Derze, G.R., and Asmus, H.E., 1981. Mapa geologico do Brasil e da area oceanica
adjacente incluindo depositos minerais, escala 1:2500000. adjacente incluindo depositos minerais, escala
Brasil, Departamento Nacional da Produç3̃o Mineral.

Snelling, N.J. and Berrangé, J.P., 1970 . The geochronology of Guyana II -results obtained during the period 1966-1969. Proceedings 8th Guiana Geological Conference, Georgetown, 1969, Guyana Geological Survey Department Paper 4, p. 1-15. 